\title{
BUDAYA MERANTAU MASYARAKAT DAN PERMASALAHAN PENDAFTARAN PEMILIH PADA PILKADA DI SUMATERA BARAT
}

\author{
Mega Ardila ${ }^{1} *$, Asrinaldi ${ }^{2}$

\begin{abstract}
An accurate, comprehensive and up-to-date voter list is an absolute prerequisite that must fulfill in carrying out electoral democracy. The existence of a correct voter list will improve the quality of the democratic electoral process by opening the most extensive possible space for citizens to exercise their right to vote. The purpose of this study was to find out the cultural implications of migrating the community in Lubuk Tarok sub-district to voter registration with the Dejure pattern. This research was carried out with qualitative methods through in-depth interviews with various informants equipped with existing documents. The results of this study show that due to the de jure pattern in voter registration has caused a large number of voters registered in the permanent voter list, but the voters are not by the KTP address. It is due to the wander culture in the Lubuk Tarok sub-district. Many of the residents of Lubuk Tarok are wandering out, but their population administration still listed in the Tarok. It is caused by many voting invitations to be returned by KPPS because there were no voters registered in the voter list. Also, this also has implications for the low level of voter participation on election day in the Lubuk Tarok sub-district.
\end{abstract}

Keywords: Merantau Culture, Voter Registration, De J ure Pattern, Election

\section{A. PENDAHULUAN}

$\mathrm{K}$ isruh daftar pemilih selalu menjadi masalah yang berulang di Indonesia. Isu problematika permasalahan daftar pemilih puncaknya mencuat dan menjadi perdebatan hangat pada pemilu tahun 2009 sejak ditetapkannya Daftar Pemilh Tetap (DPT) oleh KPU. Hasil audit daftar pemilih Pemilu 2009 yang dilakukan oleh Lembaga Penelitian Pendidikan dan Penerangan Ekonomi dan Sosial (LP3ES) terhadap daftar pemilih sementara (DPS) pada JuliAgustus 2008 menunjukkan sekitar 20,8 persen warga negara berhak memilih belum terdaftar. Laporan Tim Penyelidikan Pemenuhan Hak Sipil dan Politik dalam Pemilu Legislatif 2009 oleh Komisi Nasional

\footnotetext{
${ }^{1}$ Graduate Student of Tata Kelola Pemilu, FISIP, Universitas Andalas

${ }^{2}$ Department of Political Science, FISIP, Universitas Andalas

*Corresponding Author: bundanyaalief@gmail.com
}

Hak Asasi Manusia (Komnas HAM) menunjukkan terdapat sekitar 25-40 persen pemilih kehilangan hak pilih karena tidak masuk daftar pemilih (Asy'ari, 2012: 4-5).

Seolah tidak mau belajar dari kesalahan pada pemilu tahun 2009, begitupun pada pemilu tahun 2014 yang lalu permasalahan serupa masih terjadi. Meskipun pada pemilu tahun 2014 yang lalu dianggap lebih baik dibandingkan pemilu sebelumnya dalam proses pemutakhiran dan penyusunan daftar pemilih dilihat dari sudut transparansi dan keakuratan data. Akan tetapi penundaan penetapan DPT secara nasional pemilu legislatif tahun 2014 pun terjadi.

Penetapan DPT secara nasional yang sedianya dilaksanakan pada 23 Oktober 2013 akan tetapi ditunda penetapannya hingga 4 November 2013. Selain karena desakan Komisi II DPR dan partai politik yang menolak DPT ditetapkan kala itu, KPU mengambil keputusan itu karena adanya 
rekomendasi dari Badan Pengawas Pemilu (Bawaslu) sebagaimana tertuang dalam Surat Bawaslu Nomor 762/Bawaslu/X/2013. Pada lampiran surat tersebut, Bawaslu menyebut masih terdapat 10,8 juta data yang masih bermasalah, di antara nya masih ada Nomor induk kependudukan yang bermasalah dan terdapat pemilih siluman (pemilih yang tidak memenuhi syarat sebagai pemilih dan masih terdaftar di daftar pemilih tetap). Selain itu juga memang masih ada perbedaan data antara data di DPT dan data di Sistem Informasi Data Pemilih. (KPU, 2015: 33).

Permasalahan daftar pemilih ini terus berulang bahkan pada Pilkada serentak tahun 2015 yang lalu. Kabupaten Sijunjung yang merupakan salah satu Kabupaten di Sumatera Barat yang juga melaksanakan Pilkada serentak tahun 2015. Komisi Pemlihan Umum Kabupaten Sijunjung telah menetapkan Daftar Pemilih Tetap Pemilihan Kepala Daerah sebesar 147,278 pemilih. Akan tetapi pada hari pemungutan suara masih terdapat pemilih yang belum terdaftar pada daftar pemilih sehingga menggunakan KTP /KK dan identitas lainnya di hari pemilihan untuk mencoblos sebanyak 1321 pemilih. Akan tetapi jumlah tersebut belum lagi bagi mereka yang tidak terdaftar di DPT, akan tetapi tidak datang ke TPS karena tidak mengetahui prosedur memilih dengan menggunakan KTP pada hari pemilihan.

Selain permasalahan pemilih yang tidak terdaftar, ada juga pemilih yang tidak memenuhi syarat untuk memilih masih terdaftar pada daftar pemilih tetap pemilihan Bupati dan Wakil Bupati Kabupaten Sijunjung pada tahun 2015. Hal ini dapat dilihat dari masih adanya formulir C6 (undangan memilih) yang dikembalikan oleh Petugas Pemungutan Suara (PPS) ke KPU Kabupaten Sijunjung. Sebanyak 5.732 pemilih yang tidak memenuhi syarat yang masih terdapat di daftar pemilih tetap pemilihan Bupati dan Wakil Bupati di Kabupaten Sijunjung yang bisa kita lihat pada Tabel 1berikut :

\section{Tabel 1: Rekapitulasi Formulir C-6 Yang di kembalikan ke KPU Kabupaten Sijunjung Pada Pemilihan Bupati dan Wakil Bupati Kabupaten Sijunjung 2015}

\begin{tabular}{|c|c|c|c|c|c|c|c|c|c|c|}
\hline No & $\begin{array}{c}\text { Formulir C6-KWK } \\
\text { yang dikembalikan }\end{array}$ & 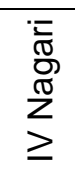 & 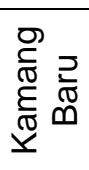 & 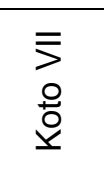 & 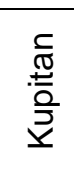 & 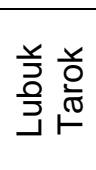 & $\begin{array}{l}\text { D } \\
\stackrel{5}{5} \\
\stackrel{5}{5} \\
: \bar{n}\end{array}$ & 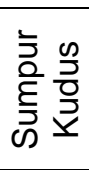 & 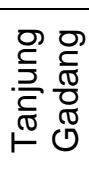 & Jumlah \\
\hline 1. & Pemilih Ganda & 253 & 209 & 433 & 64 & 114 & 72 & 52 & 213 & 1.410 \\
\hline 2. & Meninggal Dunia & 30 & 17 & 46 & 4 & 36 & 1 & 22 & 19 & 175 \\
\hline 3. & Alih Status TNI/Polri & & 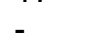 & 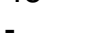 & 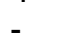 & 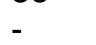 & ${ }^{\circ}$ & 1 & 1 & 2 \\
\hline 4. & $\begin{array}{l}\text { Tidak diketahui/tidak } \\
\text { dikenal }\end{array}$ & 101 & 220 & 450 & 30 & - & 165 & 43 & 111 & 1.320 \\
\hline 5. & Pindah domisili & 145 & 176 & 173 & 164 & 19 & 85 & 67 & 155 & 1.055 \\
\hline \multirow[t]{2}{*}{6.} & Alasan lain & 52 & 343 & - & 187 & 769 & 299 & 146 & 74 & 1.770 \\
\hline & Total & 581 & 965 & 1.102 & 449 & 1109 & 622 & 331 & 573 & 5.732 \\
\hline
\end{tabular}

Sumber : Berita Acara Pengembalian C6 KPU Sijunjung Tahun 2015

Pada tabel 1 tersebut bahwa jumlah undangan memilih (model C6) yang dikembalikan oleh KPPS kepada PPS terbanyak di Kecamatan Lubuk Tarok 1109. Jumlah tersebut terntunya sangat banyak jika dibandingkan dengan kecamatan lain yang memiliki daftar pemilih yang lebih besar dari Lubuk Tarok. Apakah yang menyebabkan hal tersebut

Beberapa kajian mengenai pendaftaran pemilih seperti Hasyim asyari dalam tulisannya pada Jurnal Pemilu dan Demokrasi yang berjudul "Arah Sistem Pendaftaran Pemilih Indonesia: Belajar Dari Pengalaman Menuju Perbaikan". ${ }^{1}$ Dalam hal ini Hasyim membahas permasalahan daftar pemilih langsung kepada level aplikasi

\footnotetext{
${ }^{1}$ Hasyim Asyari , 2012 "Arah Sistem Pendaftaran Pemilih Indonesia: Belajar Dari Pengalaman Menuju Perbaikan, Jurnal Pemilu dan Demokrasi, Februari 2012 (2):1-33
} 
dengan mengelompokkan 3 isu krusial dalam, yaitu siapa yang dimasukkan daftar pemilih, siapa yang melakukan pendaftaran pemilih, dan apakah pendaftaran pemilih itu hak atau kewajiban. Hasyim(2012) melakukan perbandingan dari Pemilu 2004, Pemilu 2009 dan Pilkada, ditemukan sejumlah masalah yang memerlukan penanganan serius. Dalam penelitian ini hasyim 92012) mengkaji permasalahan pada pendaftaran pemilih dari level application.

Penelitian oleh Daud M.Liando, Zulkifli Golonggom dan Michael Mamentu ${ }^{2}$ Program Pascasarjana Universitas Sam Ratulangi yang berjudul "Manajemen Daftar Pemilih Dalam Penyelenggaraan Pemilihan Umum Legislatif Di Provinsi Sulawesi Utara Tahun 2014". Dalam penelitian ini digunakan konsep yang dikemukakan oleh George R. Terry dengan fungsi manajemen yaitu Planning, Organizing, Actuating dan Controling dalam managemen pengelolaan daftar pemilih. Penelitian yang di lakukan pada Pemilihan Umum Legislatif di Sulawesi Utara tersebut menghasilkan kesimpulan bahwa manajemen pengelolaan daftar pemilih dalam penyelenggaraan pemilihan umum legislatif di Provinsi Sulawesi Utara belum berjalan dengan baik karena fungsi perencanaan, pengorganisasian, penggerakan dan pengawasan belum sepenuhnya diterapkan dalam pengelolaan daftar pemilih.

Dalam buku Seri Demokrasi Elektoral yang berjudul Menjaga Kedaulatan Pemilih yang ditulis oleh Ramlan Surbakti, Didik Supriyanto dan Hasyim Asyari bahwa untuk menjadi kedaulatan rakyat perlu sistem pemilu yang bertujuan menjamin peluang semua warga negara yang berhak memilih untuk terdaftar sebagai pemilih, menjamin semua warga negara yang terdaftar mendapat kemudahan untuk menggunakan

2 Daud M.Liando, Zulkifli Golonggom dan Michael Mamentu, “ Manajemen Daftar Pemilih Dalam Penyelenggaraan Pemilihan Umum Legislatif di Provinsi Sulawesi Utara Tahun 2014" dalam Jurnal IImu Sosial \& Pengelolaan Sumberdaya Pembangunan, Januari-Februari 2016, 3 (XX) : 1-19 hak pilihnya, melindungi suara yang diberikan pada proses pemungutan dan penghitungan suara sehingga ikut menentukan hasil pemilu.

Ketiga tulisan diatas sangat menarik, namun hanya mengkaji kepada aspek rule application saja, belum ada penelitian yang menyentuh dan fokus keterkaitan budaya merantau dalam dengan kualitas daftar pemilih terutama dengan penerapan pola dejure dalam pendaftaran pemilih ini.

\section{B. METODE PENELITIAN}

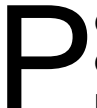
enelitian ini dilakukan dengan metode deskriptif kualitatif melalui wawancara mendalam dengan berbagai informan kunci yaitu penyelenggara pemilu di Kabupaten Sijunjung (KPU dan panitia ad hock) serta Dinas Kependudukan dan Catatan Sipil Kabupaten Sijunjung dan Peserta Pemilu. Selain itu sumber tertulis (data sekunder) berupa hasil penelitian dan dokumen resmi dari instansi yang berwenang. Analisis dilakukan berdasar kan pandangan-pandangan informan (emik) yang sudah divalidasi dengan meng gunakan metode triangulasi data. Kesimpulan dari analisis yang dilakukan terkait pada gabungan data yang didapat dari informan (emik) dan interpretasi peneliti (etic) terhadap data lapangan tersebut.

\section{HASIL DAN PEMBAHASAN}

\section{Budaya Merantau Masyarakat Lubuk Tarok Dan Pola Dejure Dalam Pendaftaran Pemilih}

$\mathrm{M}$ erantau memiliki arti berlayar atau mencari penghidupan di tanah rantau atau pergi ke negeri lain untuk mencari penghidupan, ilmu, dan sebagainya (Kamus Besar Bahasa Indonesia). Merantau telah menjadi budaya hidup banyak orang di Indonesia. Budaya merantau di ranah Minangkabau memiliki arti sebagai proses interaksi masyarakat Minangkabau dengan dunia luar. Merantau 
sebagai bentuk perjalanan ke negeri orang hampir menjadi keharusan bagi setiap orang bujang (sebutan untuk anak laki-laki di Minangkabau) dalam masyarakat Minangkabau tradisional, karena dengan membuktikan kesuksesannya di rantau, si Bujang itu besar kemungkinannya lebih sukses dalam berbagai hal yang menyangkut adat seperti perkawinan, kehormatan, kedudukan dalam suku, dan sebagainya (H. Geertz, 1967: 84 dalam Kato, 2005: 147).

Namun, sesuai dengan perkembangan zaman dan meningkatnya emansipasi wanita, merantau saat ini tak hanya dilakukan oleh anak bujang (anak laki-laki) saja, namun juga anak gadih (sebutan untuk anak perempuan di Minangkabau). Budaya merantau ini sudah dilakukan oleh masyarakat Minangkabau sejak berabadabad silam. Suku Minangkabau terkenal dengan suku yang berbudaya, memiliki kecepatan dalam beradaptasi dengan suku dan wilayah lainnya, dan cakap dalam berkomunikasi. Hal ini yang akhirnya menjadikan suku minangkabau banyak yang melakukan kegiatan merantau seperti halnya terjadi di kecamatan lubuk tarok kabupaten sijunjung. Kecamatan Lubuk Tarok yang meliputi 3 nagari yaitu Lalan, Buluh Kasok dan Lubuk Tarok. Selain adat istiadatnya yang masih kuat, banyak rumahrumah adat dipertahankan keberadaannya. Mata pencaharian penduduk setempat bertani dan berkebun, sebagian juga banyak yang merantau ke Negeri Jiran Malaysia.

Menariknya ternyata kebudayaan merantau yang ada di kecamatan lubuk tarok ini berpengaruh kepada kualitas daftar pemilih di kabupaten sijunjung. Bahwa secara de jure pemilih tersebut kediaman Pemilih adalah berdasarkan KTP, akan tetapi secara de facto tidak ada di alamatnya seperti karena alasan merantau. Bahwa banyak diantara masyarakat lubuk tarok yang merantau keriau bahkan ke negeri jiran malaysia akan tetapi administrasi kependudukan nya masih di Kabupaten Sijunjung. Wawancara dengan PPDP Sungai Jodi:

"Di Lubuak Tarok ko banyak yang merantau ka Aia Molek, Malaysia
Pakanbaru, alah jadi tradisi disiko alah batahun-tahun marantau disinan, tapi KTP masih Sijunjuang, waktu ambo mandata keluarga ndak nio namo-namo keluarga nyo nan marantau ko dihilangan dari data pamilihan, nan ambo yo takuik pulo untuk mancoret, itu samo sajo manghilangkan hak urang pidana jatuah nyo"3

( Di Lubuk Tarok ini banyak yang merantau ke Air Molek, Malaysia, dan Pekanbaru sudah jadi tradisi disini mereka sudah lama merantau, bertahun-tahun sudah mempunya rumah disana akan tetapi KTP masih Sijunjung, waktu saya mendata keluarga tidak mau nama-nama keluarga nya yang merantau tersebut dihilangkan dari data pemilih, dan saya tentunya tidak berani juga mencoretnya, karena itu sama juga dengan menghilangkan hak orang, pidana nanti jatuhnya )

Hal yang sama dikemukakan oleh Yose Rizal, PPK Lubuk Tarok:

"Memang banyak di Lubuk Tarok ini warga yang merantau ke luar dari Kabupaten Sijunjung tapi nama-nama nya masih ada di daftar pemilih, tentunya kami bisa mencoret nama tersebut apabila keluaga nya mengizinkan, akan tetapi waktu itu keluarga tidak mau, karena mereka takut juga kalau hilang nama nya dari daftar pemilih di Pilkada berarti mereka beranggapan bahwa keluarganya tersebut bukan warga Sijunjung lagi dan segala hak mereka sebagai warga Sijunjung turut hilang" ${ }^{\prime 4}$

Mengenai hal tersebut peneliti mewawancarai keluarga yang merupakan keluarga perantau yang merantau ke Malaysia:

\footnotetext{
${ }^{3}$ Wawancara dengan ZK PPDP Jorong Sungai Jodi, tanggal 3 Februari 2018

${ }^{4}$ Wawancara dengan Yose Rizal PPK Lubuak Tarok, tanggal 3 Februari 2018
} 160 | P a g e 
"Bapak marantau di Malaysia, lah lamo disitu, karajo disitu dibawo dek keluarga. wakatu urang mandata dulu apak lai dirumah, apak emang pas lagi pulang dari Malaysia, wakatu itu kan lagi puaso nio ka rayo, jadi apak waktu itu pulang dalam rangka hari rayo, apak pulang sakali satahun pas rayo biasonyo" 5

( Bapak merantau di Malaysia, sudah lama disana, kerja disana dibawa oleh keluarga yang disana juga, waktu petugas pemilu mendata dulu bapak pas lagi pulang, waktu itu kalau tidak salah orang puasa mau lebaran jadi bapak waktu itu pulang dala rangka Idul Fitri, kebetulan bapak emang pulang biasanya sekali setahun pas leberan tersebut. )

Informan lain juga menyebutkan :

"Anak ambo merantau ke Air Molek,di disitu basamo suami dan anak-anak nyo, duo anak ambo disitu, adiak nyo juo di Aia Molek, manggaleh di pasa aia molek. Waktu petugas mendata kapatang tu kami emang indak manyuruah petugas manghapuih namo anak tu, mano tau nanti pas pemilihan nyo lai pulang kan bisa juo mamilih " 6

( Anak saya merantau ke Air Molek, disitu bersama suami dan anakanaknya,, anak saya berdua di Air Molek adikya juga disana, bekerja berjualan di pasar Air Molek. Waktu petugas mendata kemaren kami memang tidak mengiizinkan petugas menghapusnya dala data pemilih karena mana tau nanti pas hari pemilihan mereka pulang kan bisa juga memilih"

Dari hasil wawancara dengan Lindo Karsyah:

\footnotetext{
5 Wawancara dengan Rizka keluarga dari perantau, tanggal 3 Februari 2018

${ }^{6}$ Wawancara dengan Zuryenti keluarga

perantau, tanggal 3 Februari 2018
}

\begin{abstract}
"Masalah Lubuk Tarok dari pemilu ke pemilu selalu saja hal yang sama, dimana banyak dari warga disana yang merantau akan tetapi administrasi kependudukan nya masih di Sijunjung sehingga namanama mereka tetap ada di daftar pemilih kita dan tidak ada regulasi yang mengizinkan kita menghapus nama-nama tersebut karena hal tersebut sama saja kita menghilangkan hak pilih seseorang meskipun pada hari $\mathrm{H}$ kemungkinan mereka akan pulang memilih snagat tipis sehingga hal ini menyebabkan rendahnya tingkat partisipasi kita di Sijunjung khususnya Lubuk Tarok, kalau kita lihat kasat mata lebih dari $80 \%$ pemilih di Lubuk Tarok memilih akan tetapi tingkat partisipasi disana tidak pernah melampaui $50 \%$ dari tahun ke tahun, hal ini karena banyaknya pemilih yang didata akan tetapi secara defacto mereka tidak di Lubuk Tarok."
\end{abstract}

Berdasarkan wawancara di atas dapat disimpulkan bahwa banyak nya pemilih yang terdata di dalam data pemilih karena berpedoman kepada nama-nama yang sudah tersedia di dalam formulir A-KWK yang dibawa oleh petugas dalam proses pencocokan dan penelitian dilapangan. Data yang berasal dari daftar pemilih potensial pemilih yang secara dejure berdasarkan KTP berdomisili di Kabupaten Sijunjung, padahal secara fisik mereka sudah tidak berdomisili di Kabupaten Sijunjung. Dalam hal ini regulasi memang tidak mewajibkan untuk menghapus mereka dalam daftar pemilihan selama keluarga yang bersangkutan tidak menginginkan hal itu. Hal tersebut juga dapat dilihat pada rekapitulasi formilir C6 yang dikembalikan dapat terlihat bahwa pada Kecamatan Lubuk Tarok merupakan Kecamatan yang paling banyak kembali formulir C6 (undangan memilih). Hal ini menggam barkan bahwa banyak dari pemilih yang

\footnotetext{
${ }^{7}$ Wawancara dengan Lindo Karsyah Komisioner Divisi Sosialisasi dan Data, 7 Februari 2018
} 
masuk ke dalam daftar pemilih tetap akan tetapi sewaktu KPPS memberikan surat undangan memilih yang bersangkutan tidak ada di Kecamatan Lubuk Tarok.

Hal ini yang membuat prinsip mutakhir sebagai salah satu prinsip yang harus dipenuhi dalam menyusun daftar pemilih tidak terwujud karena daftar pemilih tidak memuat informasi terkini dalam daftar pemilih. Hal ini juga merupakan implikasi dari mekanisme pendaftaran pemilih yang berbasis administrasi kependudukan, dimana keakuratan data sangat tergantung kepada informasi kependudukan yang dimiliki pemerintah. Dalam hal ini bukan hal yang aneh bagi sejumlah besar orang di dalam sebuah komunitas untuk bergerak baik di dalam negeri untuk meninggalkan tanah kelahirannya untuk sementara atau selamanya karena keadaan ekonomi atau keadaan lainnya. Dalam kasus tersebut, mungkin ada nama surplus dalam daftar dalam daftar pemilih akan tetapi kebanyakan dari mereka tidak berkesempatan hadir dihari pemilihan (OSCE/ODHR, 2012:12). Oleh karena itu lah hal ini juga menyebabkan rendahnya partisipasi pada Kabupaten Sijunjung, karena kebanyakan nama-nama yang ada dalam daftar pemilih tersebut tidak datang ke TPS karena memang sudah tidak berdomisili di Kabupaten Sijunjung.

\section{KESIMPULAN}

B udaya merantau yang terdapat di Kecamatan Lubuk Tarok sehingga menyebabkan banyaknya pemilih yang terdaftar dalam daftar pemilih tetap yang mana secara dejure berdasarkan kartu identitas kependudukan mereka beralamat kan di Lubuk Tarok, Akan tetapi secara de facto keberadaan mereka tidak tercatat di Lubuk Tarok oleh karena beberapa alasan terurtama karena merantau ke Provinsi lain bahkan Negara lain seperti Malaysia. Permasalahan ini juga yang membuat surplus pada daftar pemilih sehingga rendahnya tingkat partisipasi di Kabupaten Sijunjung.

\section{E. UCAPAN TERIMA KASIH}

A rtikel ini merupakan hasil penelitian yang dibiayai oleh Komisi Pemilihan Umum Republik Indonesia. Peneliti mengucapkan terima kasih kepada semua pihak yang sudah membantu penelitian ini terlaksana sehingga sebagian hasilnya bisa dipublikasikan di jurnal ini.

\section{DAFTAR PUSTAKA}

Abdullah, Rozali.(2009). Mewujudkan Pemilu Yang Lebih Berkualitas (Pemilu Legislatif). Jakarta: PT Raja Grafindo Persada.

ACE-Electoral Knowledge Network, (2012) "Voter Registration", dan "General Issues". ACE Electoral Knowledge Network

Asya'ri, Hasyim. (2012). Arah Sistem Pendaftaran Pemilih Indonesia: Belajar Dari Pengalaman Menuju Perbaikan. Jurnal Pemilu Dan Demokrasi. 2: 1-31

IDEA.(2010). Electoral Justice. The International IDEA Handbook. International. Sweden: IDEA

IDEA.(2002). Standar-standar Internasional untuk Pemilihan Umum Pedoman Peninjauan Kembali Kerangka Hukum Pemilu. Sweden: IDEA

Kadir, Abdul \& Suaib Eka, Susilo Suko. (2015). Accurate Data Management for Voter (Case of Indonesia). Australian Journal of Basic and Applied Sciences. 9(11): 952-959

Kato, T. (2005). Adat Minangkabau dan merantau dalam perspektif sejarah. Balai Pustaka

Khoirunnisa, Agustyati (2016) Menata Ulang Mekanisme Pendaftaran Pemilih Pilkada, Jurnal Pemilu Dan Demokrasi. 8 (-): 43-62

Mozaffar and Schedler (2002), The Comparative study of Electoral Governance, Journal International Political Science, 23(1): 5-27

Marchetti (2012), Electoral Governance in Brazil, Journal Brazilian Political Siences, 6 I(X): 113-133

162 | P a g e

DOI: 10.25077/jantro.v20.n2.p157-163.2018

JANTRO ISSN: 2355-5963 (Online)

under Lisensi Creative Commons Atribusi-BerbagiSerupa 4.0 Internasional 
Nurmandi, \& Eka, Bambang \& Darumurti (2015). Strategi Pelembagaan Good Governance Dalam Proses Pemilu Di Indonesia. Laporan penelitian hibah bersaing Perguruan Tinggi Negeri, Yogyakarta: Dikti

OSCE/ODHIR. (2012). Handbook For The Observation Of Voeter Registration, Poland: Osce Office for democratic institutional

Sadikin, Usep Hasan \& Hafidz Masykurudin (2017), Penyelenggaraan Pilkada Serentak 2015 dan 2017, Jakarta : Komisi Pemilihan Umum

Suaib, Eka (2010). Problematika Pemutakhiran Data Pemilih Di Indonesia. Depok:Koekoesan

Surbakti, Supriyanto, \& Asya'ri (2011). Seri Demokrasi Elektoral: Menjaga Kedaulatan Pemilih, Jakarta: Kemitraan.

Surbakti, Supriyanto, \& Asya'ri (2012). Seri Demokrasi Elektoral: Meningkatkan Akurasi Daftar Pemilih, Jakarta: Kemitraan.

Torres \& diaz (2011), Electoral Governance More Than Electoral Administration, Journal Mexico Law, VII(1) : 31-46 